Synthesis, part of a Special Feature on Resilience and Vulnerability of Arid and Semi-Arid Social Ecological Systems

\title{
Vulnerability of Worldwide Pastoralism to Global Changes and Interdisciplinary Strategies for Sustainable Pastoralism
}

\author{
$\underline{\text { Shikui Dong }}^{1,2}, \underline{\text { Lu Wen }}^{1}$, Shiliang Liu ${ }^{1}, \underline{\text { Xiangfeng Zhang }}^{1}$, James P. Lassoie $^{2}$, Shaoliang Yi ${ }^{3}$, \\ ${\underline{\text { Xiaoyan } \mathrm{Li}^{1}}}^{1}$, Jinpeng $\mathrm{Li}{ }^{1}$, and Yuanyuan $\mathrm{Li}^{1}$
}

\begin{abstract}
Ten case studies from seven major pastoral regions across six continents were studied in this paper by conceptualizing three factors (agro-ecosystem resilience, livelihood options, and institution capacity) as the axes of a three-dimensional vulnerability framework. This analysis highlights the vulnerability of agriculture-based livelihood systems to global changes and helps identify what institutions have the potential to mobilize effective relief in different pastoral regions. In terms of results, this vulnerability assessment shows that the vulnerability of pastoralism was very different in all the cases across the globe. As such, a further analysis, based on the pressure-state-response (PSR) model was undertaken to enhance our understanding of the ways that global changes put pressures on pastoral livelihoods worldwide. From this we conclude that climate change and climate variability are driving fragile pastoral ecosystems into more vulnerable conditions. Socioeconomic factors, such as changes in land tenure, agriculture, sedentarization, and institutions are fracturing large-scale pastoral ecosystems into spatially isolated systems. The implications of this analysis are that professionals, practitioners, and policy makers should jointly develop a coupled human and natural systems approach that focuses on enhancing the resilience of pastoral communities and their practices. This requires institutional developments to support asset building and good governance to enhance adaptive capability. In addition, pastoralists' adaptation strategies to global change need to be supported by public awareness and improved by institutional decisions at different scales and dimensions.
\end{abstract}

Key Words: adaptation management; global change; pastoral systems; resilience enhancement; vulnerability mitigation

\section{INTRODUCTION}

Pastoralism is a livestock production system that is based on extensive land use and often some form of herd mobility, which has been practiced in many regions of the world for centuries (WISP 2007). Currently, extensive pastoralism occurs on about $25 \%$ of the earth's land area, mostly in the developing world, from the drylands of Africa and the Arabian Peninsula, to the highlands of Asia and Latin America where intensive crop cultivation is physically not possible (FAO 2001). In addition, cattle and sheep ranchers in Western North America, Australia, New Zealand, and a few other regions of the world presently practice a modern form of pastoralism. Worldwide, pastoralism supports about 200 million households and herds of nearly a billion head of animals including camel, cattle, and smaller livestock that account for about $10 \%$ of the world's meat production (FAO 2001). Pastoralism is globally important for the human populations it supports, the food and ecological services it provides, the economic contributions it makes to some of the world's poorest regions, and the long-standing civilizations it helps to maintain (Nori and Davies 2007). Unfortunately, threats and pressures associated with human population growth, economic development, land use changes, and climate change are challenging professionals and practitioners to sustain and protect these invaluable social, cultural, economic, and ecological assets worldwide (Nori and Davies 
Fig. 1. Three-dimensional vulnerability-coordination framework in assessing vulnerability of pastoralism. In the dimensions of agroecosystems on which pastoralists depend, options that allow pastoralists to react and institution capacity to respond to crises in pastoral systems: octant 1 is robust, abundant, and high; octant 2 is fragile, abundant, and high; octant 3 is robust, abundant, and low; octant 4 is fragile, abundant, and low; octant 5 is robust, limited, and high; octant 6 is fragile, limited, and high; octant 7 is robust, limited, and low; octant 8 is fragile, limited, and low. At agroecological, livelihood, and institutional scales, the movement to octant 8 indicates increased vulnerability of pastoralism to global climate change and octant 1 implies decreased vulnerability of pastoralism to global climate change (Adapted from Fraser 2007).

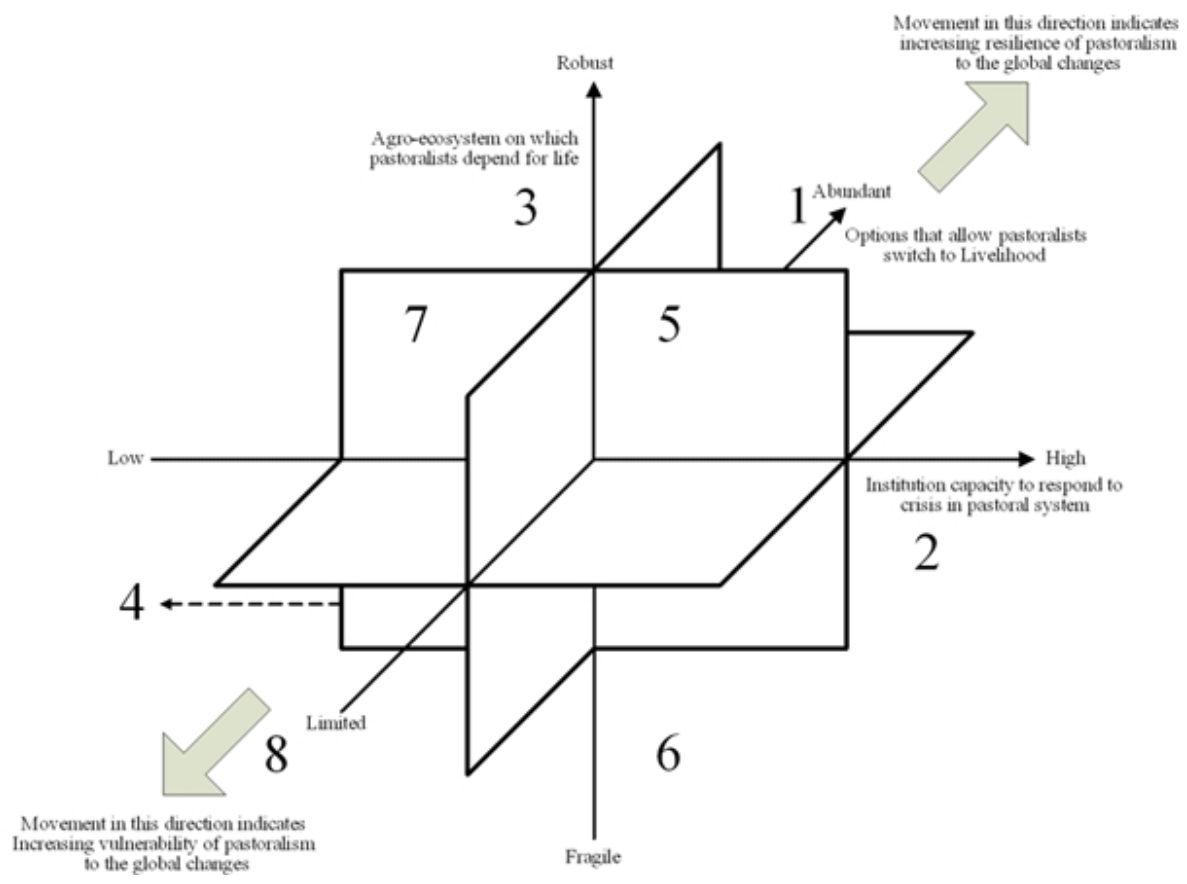

2007). Key ecosystem services such as biodiversity and food production provided by rangeland ecosystems may be vulnerable to both changes in climate as well as large-scale socioeconomic forces (Schröter et al. 2005, Abildtrup et al. 2006).

Vulnerability "is the sensitivity of people, places, ecosystems and species to contingencies and stress, and their capability to cope with them" (MEA 2005:146). The vulnerability of food systems, including pastoral production systems, to climate change can be assessed via the dimensions of agroecosystems, livelihoods, and institutions (Fraser 2007). However, the ways of measuring these three factors will vary from place to place, making direct comparisons difficult (Fraser 2007). By conceptualizing these three variables as the axes of a three-dimensional "vulnerability" coordination framework by referring to Fraser (2007) and Dougill et al. (2010), it is possible to compare different geographical regions and examine trends over time by studying the paths through the octant as traced by changes in the agroecosystem, livelihood, and/ or institutional dimensions (Fig. 1). Additional analysis is needed, however, to fully understand cause and effect relationships within this framework.

The pressure-state-response (PSR) framework developed by the Organization for Economic Cooperation and Development (OECD) has been widely used by international environmental agencies to identify the cause and effect chains of the vulnerability in natural resource use and environmental protection (Waheed 2009). According to PSR theory, social and economic conditions will 
Fig. 2. Map of global pastoralism and case sites (modified from Nori and Davies 2007).

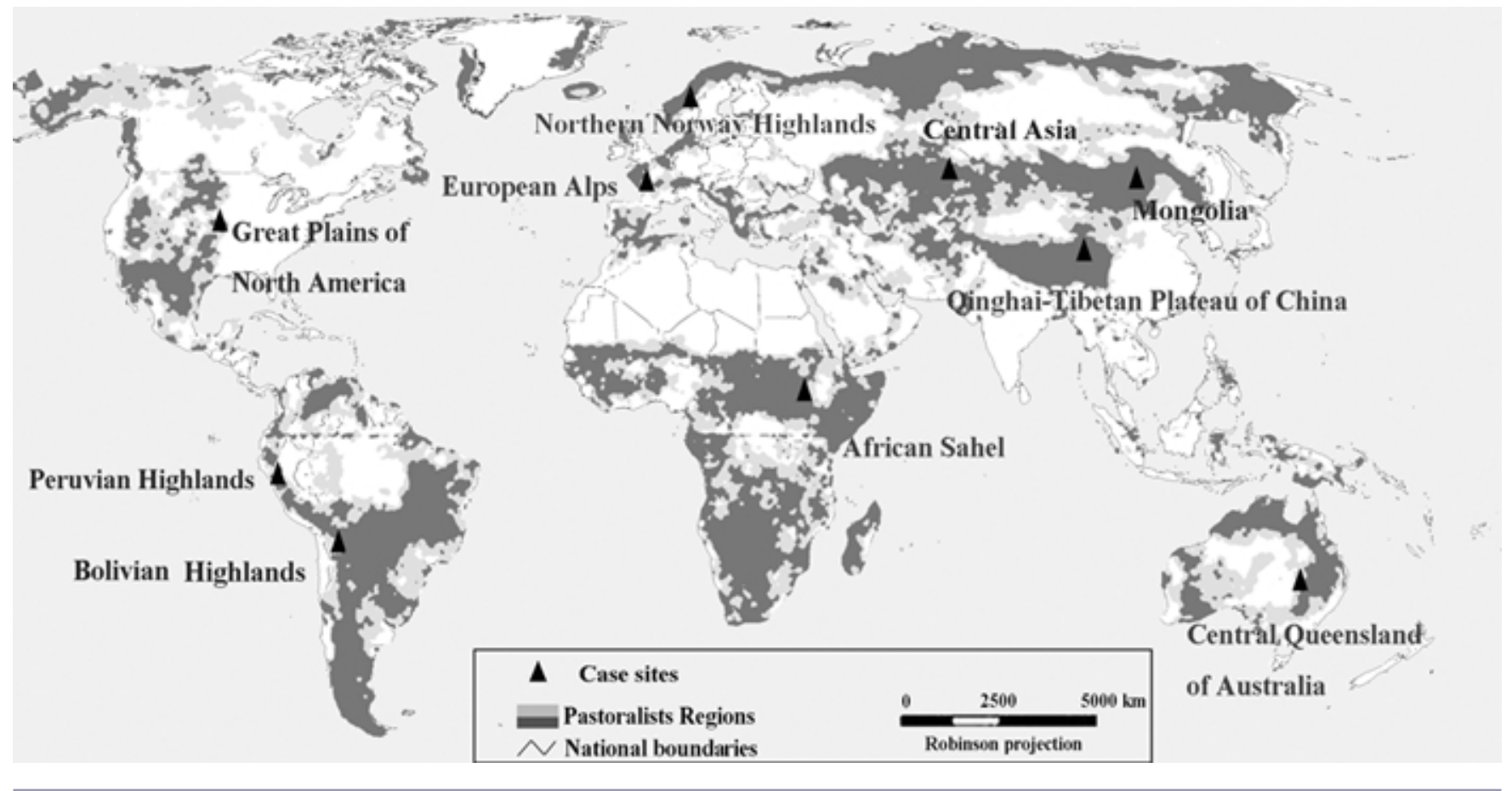

generate responses that pressure the natural environment, leading to changes in its state (Pearce and Freeman 1991), which in turn have impacts on human society that are typically negative. People then can act collectively, often via government regulations and policies, to address the pressures and impacts either by reducing the effects after they happen, or preferably by changing the driving forces or sources, thereby preventing or minimizing the environmental response that cause harm.

It is clear that globally, pastoralists and their rangelands form a vast and heterogeneous complex of diverse landscapes, cultures, and socioeconomic conditions that involve direct interactions among the natural resource base, the resource users, and the larger geopolitical system (Pratt et al. 1997). In this paper, we will summarize and synthesize this heterogeneity by using the three-dimensional vulnerability-coordination framework and PSR framework to provide a detailed analysis of how social-ecological systems of pastoralism worldwide are changing in their vulnerability to global change, and to highlight the institutional options available that might reduce their vulnerability. Specifically, we examine 10 case studies (Fig. 2) to gain a better understanding of: (1) agroecosystems that arise from pastoralism and provide livelihoods in different pastoral regions; (2) vulnerability of agroecosystem and livelihood strategies to global changes that are occurring in different pastoral regions; and (3) institutional capabilities that can mobilize effective relief of the vulnerability associated with global changes.

\section{CASE STUDIES OF GLOBAL PASTORALISM CHANGES}

\section{Decline of pastoral systems with expansion of agriculture in African Sahel}

Located in the semiarid transition zone between the Sahara desert and the subhumid savanna zone, the Sahel has been a major pastoral production zone in Africa for centuries because of its characteristic physical and climatic conditions and associated plant communities (Table 1). According to Brooks (2006), pastoral livelihoods in the Sahel historically have depended on negotiated, nonexclusive access to water and reciprocal land use agreements between pastoralists and agriculturalists. This 
Table 1. General information on the African Sahel (Kandji et al. 2006).

\begin{tabular}{ll}
\hline \hline Location & $\begin{array}{l}\text { It represents the southern edge of the Sahara desert, extending from the Atlantic Ocean in the west to the } \\
\text { Red Sea in the east, from Cape Verde to the south by the less arid Sudano-Sahelian belt, covering a surface } \\
\text { area about } 5.7 \text { million } \mathrm{km}^{2} \text {. }\end{array}$ \\
Climate & $\begin{array}{l}\text { It is a transitional zone between the arid Sahara desert in the north and subhumid savanna zone in the } \\
\text { south, with annual rainfall varying from } 200 \mathrm{~mm} \text { to } 600 \mathrm{~mm} .\end{array}$ \\
Vegetation & $\begin{array}{l}\text { Vegetation cover of the Sahel is composed of bushes, grasses, and stunted trees that increase in density as } \\
\text { one moves southward. }\end{array}$ \\
Land use & $\begin{array}{l}\text { Traditional way of utilizing the Sahel is mostly raising livestock in a system of seminomads, i.e., farming } \\
\text { and raising livestock in a system of transhumance. }\end{array}$ \\
Animals & $\begin{array}{l}\text { Grazing livestock of cattle, camel, sheep, and goats as well as wild grazing mammals such as Scimitar- } \\
\text { horned Oryx (Oryx dammah), Dama Gazelle (Gazella dama). }\end{array}$ \\
Population & $\begin{array}{l}\text { It supports a population of about } 58 \text { million inhabitants; among them about 13\% are nomadic pastoralists, } \\
\text { i.e., Tuareg, Fulani, and other ethnic groups. }\end{array}$ \\
$\begin{array}{l}\text { Social } \\
\text { problems }\end{array}$ & $\begin{array}{l}\text { The expansion of agriculture and a shift to agro-pastoralism pushed nomadic pastoralists into more } \\
\text { marginal regions. }\end{array}$
\end{tabular}

traditional system, being flexible and able to rapidly respond to changing environmental conditions, has been well suited to the ecological and sociological conditions that characterize the Sahel (Jarvis 1993, Marshall and Hildebrand 2002). However, the adaptability of pastoralism, which depends on water availability and pastureland productivity, is now being negatively impacted by unpredictable climate change, enhanced environmental degradation, and the need to increase agricultural production to meet the demands of a rapidly growing population (Grouzis 1988, Watkinson and Ormerod 2001).

According to Ahmed et al. (2000), the Sahel experienced unusually large amounts of rainfall during the 1950s and 1960s, relative to the mean for the 20th Century, which was also the transition period to independence for many African nations. During this period, as stated by Brooks (2006:4), "Newly independent African nations focused on modern, technocratic solutions to development aimed at delivering economic growth and the traditional approaches to resource management and food security were increasingly marginalized." The coincidence of political and economic transition during this period resulted in the northward expansion of agriculture into historically marginal areas of the Sahel, which lead to increased conflicts between agriculturalists and pastoralists and profound implications for both groups (Glantz 1996, Thébaud and Batterby 2001). Although the famines of the 1970s across the Sahel were undoubtedly triggered by the prolonged drought of the 1970s and 1980s, when rainfall decreased by $29-49 \%$ compared with the 1931-1960 baseline period (IPCC 2001, Claussen et al. 2003), they were significantly exacerbated by inappropriate development practices (de Bruijn and van Dijk 1999, Warren 2005). As Brooks (2006:4) stated "Over-extension of agriculture into historically marginal rangeland areas as a result of a failure to appreciate the nature of long-term (i.e., multi-decadal scale) climatic variability in the Sahel, resulted in massive losses of human life and livestock, the destruction of communities and livelihood systems, and massive societal disruption on a regional scale." Moreover, such an 'expansion only' strategy for food production led to deterioration of the land resources in the Sahel, e.g., overgrazing associated with the disappearance of fallows and the declining extent of pastures has resulted in the devastation of land resources in many areas (Kandji et al. 2006)

Although there are conflicting and uncertain patterns predicted for future rainfall in West Africa, especially in the Sahel region (Kandji et al. 2006, 
Table 2. Pastoral production in Kazakhstan, Kyrgyzstan, Uzbekistan, and Mongolia (FAO 1997, Thornton et al. 2002).

\begin{tabular}{llccccc}
\hline \hline Countries & Location & $\begin{array}{c}\text { Permanent } \\
\text { pasture }(\mathrm{km})\end{array}$ & $\begin{array}{c}\% \text { of total } \\
\text { land area }\end{array}$ & $\begin{array}{c}\text { Major } \\
\text { pastoral } \\
\text { ethnicity }\end{array}$ & $\begin{array}{c}\text { Pastoralists' } \\
\text { population }\end{array}$ & $\begin{array}{c}\% \text { of all } \\
\text { agricultural } \\
\text { population }\end{array}$ \\
\hline Kazakhstan & Central Asia & $1,851,000$ & 69 & Kazakhs & $4,700,000$ & 68 \\
Kyrgyzstan & Central Asia & 93,650 & 49 & Kyrgyz & 256,000 & 7 \\
Uzbekistan & Central Asia & 222,190 & 52 & Uzbeks & $1,478,000$ & 6 \\
Mongolia & $\begin{array}{l}\text { East and Central } \\
\text { Asia }\end{array}$ & $1,293,000$ & 83 & Mongol & $2,051,000$ \\
\hline
\end{tabular}

Christensen et al. 2007), migrations and geographical rearrangements of pastoral people in response to major shifts in rainfall variability should be expected (Bassett and Turner 2007, Galvin 2009). Future rainfall increases in the Sahel have been predicted in the Third Assessment Report of the Intergovernmental Panel on Climate Change (IPCC), but only with the most rapid global change scenario (Carter et al. 2000, Hulme et al. 2001). If this is the case, an expansion of agriculture into marginal areas of rangeland will be encouraged by current development strategies that emphasize "models of agricultural production" over pastoralism (Warren 2005). As a consequence, social conflicts between agriculturalists and pastoralists, and the problems associated with overgrazing and land resource deterioration may be accentuated. Moreover, past lessons have shown that the increasing incorporation of pastoralists into modern states in Africa has led to a progressive political, economic, and cultural marginalization of pastoral society (Azarya 1996), with some ending up living in a "world of insecurity, war, famine and drought" (Baxter 1993:143). Pastoral livelihoods and institutions will become increasingly vulnerable if current government policies continue to stress its development and "modernization" (Warren 2005).

From this case, three points can be summarized in the three-dimensional vulnerability-coordination framework for pastoral systems in the African Sahel: (1) changing pastoral systems into agricultural systems enhanced the fragility of the agroecosystem; (2) pushing pastoralists into more marginal regions with the expansion of agriculture increased the risk of limiting livelihood assets; and (3) promoting current development models aimed at delivering economic growth and marginalizing traditional resource management lowered the institutional capacity to respond to crisis. As a result, this would be reflected in a shift toward the octant 8 in Figure 1, indicating an increase in the vulnerability of pastoralism to global changes with respect to the functioning of livelihoods, agroecosystems, and institutions.

\section{Marginalization of pastoral systems with collapse of command economy in Central Asia and Mongolia}

The Central Asian republics have an estimated pasture area of 250 million ha that form part of an even larger region of arid lands including parts of Russia, Mongolia, and China (FAO 1997). Pasturelands cover nearly half or more of the lands in three Central Asian nations, Kazakhstan, Uzbekistan, and Kyrgyzstan (Table 2). The primary land use across this vast area in the past was extensive migratory livestock production, and boundaries were not rigidly defined by the state (Suleimenov and Oram 2000). Driven by the strategy of restructuring agriculture to achieve food security and to adjust to market economy requirements after the breakup of the Soviet Union in the early 1990s, pasture management has been moved from state-managed mobile systems toward 
de facto common property regimes and, more recently, to leasing or privatization (Robinson et al. 2010). A wave of land privatization reforms has shifted land rights from pastoral cooperatives to wealthy individuals and groups, which has crowded out the poorest segment of the population, resulting in their growing insecurity over access to resources and the ability to exercise various mobile grazing options (Nori et al. 2005). Transformation of the traditional pasture-use system, driven mostly by population growth and policy reform, has resulted in massive rangeland degradation and increased carbon emissions in this area (Chuluun and Ojima 2002).

Although the consequences of changing property rights on rangeland as well as livestock management are quite different in Kazakhstan, Kyrgyzstan, and Uzbekistan, many common problems are challenging their traditional use for achieving food security and sustainable pastoral livelihood development during this economic transition period. In Kazakhstan, overstocking of rangeland is still increasing in spite of dramatic declines in total livestock numbers. With the collapse of special government services, higher livestock densities have resulted because only 30 to $40 \%$ of potential available rangeland is actually grazed, the rest either lacks drinking water or is too remote (Suleimenov and Oram 2000). The same problems have occurred in Kyrgyzstan and most rangeland has not been grazed since independence (Suleimenov and Oram 2000). However, following the collapse of state farms, a common herding system whereby pastures were continuously used by those communities that historically exploited them, has enabled partial use of remote pastures (Farrington 2005). With a statecontrolled system still in place, Uzbekistan's rangelands have been used more appropriately, but the widespread expansion of grain crops onto marginal lands is contributing to soil erosion (Suleimenov and Oram 2000).

Pastoral production has always been the mainstay of the Mongolian economy (Mearns 2004), with $83 \%$ of the nation's territory covered by rangeland and where $84 \%$ of agricultural populations are pastoralists (Table 2). During the socialist period, herders became dependent on the central government for salaries and for providing means of transporting livestock. In addition, state collectives allocated pastures, directed seasonal migrations, and provided veterinarians, fodder, and labor (Fernandez-Gimenez 2001). Although collective farms collapsed and livestock were privatized during the transition to a market economy in the 1990s, an attitude of dependency remained (Muller and Bold 1996). With the dismantling of herding collectives in 1992, formal regulatory institutions for allocating pastures such as heavy state subsidies, strong extension support, and planned markets disappeared, and weakened customary institutions were not able to replace them fully (FernandezGimenez and Batbuyan 2004). As a result, millions of hectares of sown lands, which resulted from the forced conversion of some of the most productive rangelands into croplands by Mongolia's socialist government during the $1950 \mathrm{~s}$, decreased by half and the crop production decreased about threefold in 1995 compared with 1990 (Chuluun and Ojima 2002).

A new Land Law, passed in 1994 by the postsocialist government, provided for the regulation, management, and monitoring of pastureland, as well as the leasing of campsites and potential pastures. Leasing of winter and spring campsites began in 1998. However, the vague and shifting boundaries that had been so adaptive in the past are now increasing herder vulnerability to environmental perturbations arising from climate change (Turner 1999, Fernandez-Gimenez 1999). Although a revision went into effect in 2003, it unfortunately preserved some of the ambiguities of the earlier law, and again included provisions for certificates of possession, i.e., leases, for the use of winter and spring campsites, and potential winter and spring pastures. However, summer and fall pastures were to remain open for use by all, thus preventing herders from implementing effective traditional management plans, which has negatively influenced pastoralists' livelihoods (FernandezGimenez and Bathuyan 2004, Upton 2008).

When examined relative to the three-dimensional vulnerability-coordination framework, the cases from Central Asian republics and Mongolia indicate that institutional changes in pastoralism, i.e., rangeland privatization and open access, have led to a lowered institutional capacity to respond to crisis, e.g., disappearance of formal regulatory institutions and weakened customary institutions, and increased agroecosystem degradation that increased herders' vulnerability in terms of socioeconomic affluence. These results represent a shift toward the octant 8 in Figure 1, thereby indicating an increase in the vulnerability of pastoralism at agroecosystem, institution, and livelihood dimensions. 
Table 3. General information on pastoralism on the Qinghai-Tibetan Plateau (Long et al. 1999, Dong et al. 2010).

\begin{tabular}{|c|c|}
\hline Location & $\begin{array}{l}\text { It is located in western China, covering most of the Tibet Autonomous Region and Qinghai Province in } \\
\text { China. It is the highest and biggest plateau called "the roof of the world," with an area of } 2.5 \text { million } \mathrm{km}^{2} \text {. }\end{array}$ \\
\hline Climate & $\begin{array}{l}\text { It is characterized by a dry and cold alpine climate. Annual precipitation ranges from } 100 \mathrm{~mm} \text { to } 300 \mathrm{~mm} \text {, } \\
\text { which falls mainly as hailstorms. Year-round temperatures average } 0^{\circ} \mathrm{C} \text {, dipping to }-40^{\circ} \mathrm{C} \text { in some areas } \\
\text { in winter. }\end{array}$ \\
\hline Vegetation & $\begin{array}{l}\text { Vegetation cover of the Qinghai Tibetan Plateau is mostly (over 70\%) alpine rangelands, including alpine } \\
\text { meadow, alpine shrub, alpine steppe, and alpine desert. }\end{array}$ \\
\hline Land use & $\begin{array}{l}\text { Pastoralism is the dominant way of utilizing the vast rangelands of Qinghai-Tibetan Plateau. Agro- } \\
\text { pastoralism exists in some areas. }\end{array}$ \\
\hline Animals & $\begin{array}{l}\text { Grazing livestock include yak (around } 13 \text { million, over } 90 \% \text { of world population), Tibetan sheep (Ovis } \\
\text { ammon), and goats (around } 42 \text { million), and wild grazing mammals including blue sheep (Pseudois } \\
\text { nayaur), wild ass (Equus hemionus), and wild yak (Bos grunniens). }\end{array}$ \\
\hline Population & $\begin{array}{l}\text { It supports about } 10 \text { million people, among which approximately } 52 \% \text { are nomadic pastoralists or } \\
\text { pastoralists of Tibetan or Tibetan-originated ethnicities. }\end{array}$ \\
\hline $\begin{array}{l}\text { Social } \\
\text { problems }\end{array}$ & $\begin{array}{l}\text { Conflicts over the increasing population and limited resources in pastoral areas. Change of pastoral } \\
\text { livelihoods driven by rapid economic and social development. }\end{array}$ \\
\hline
\end{tabular}

\section{Degradation of pastoral ecosystem with overusing and warming on Qinghai-Tibetan Plateau of China}

The vast areas of Qinghai-Tibetan Plateau (QTP) of China are the headwaters for three Asian rivers, the Yangtze, Yellow, and Langcang-Mekong, and are predominately covered by rangelands that have been used by Tibetan communities as pasturelands for the subsistence grazing of livestock, e.g., yak (Bos grunniens) and Tibetan sheep (Ovis ammon), for millennia (Table 3). However, pastoralism in the fragile and vulnerable landscapes of the QTP is being threatened by rangeland degradation that is associated with population growth, climatic warming, and policy changes.

The rangelands of the central QTP have been overused in recent decades by rapidly increasing human and livestock populations (Ma et al. 1999, Wang and Chen 2001, Shang and Long 2005). Some scholars (Riley 2004, Fischer 2008) report that the population growth rates of Tibetans and Kazaks were about double that of Han during 1982-2000, although it is difficult to accurately estimate such growth rates for pastoralist populations because of methodological sampling issues including the selection of appropriate time periods (Fischer 2008). With the building of a new railway into Tibet in 2006, more immigrants are expected into this traditionally pastoral region (Bauer 2005), likely resulting in the overpopulation of outsiders in pastoral societies similar to other parts of western China (Banks et al. 2003). Population growth in pastoral areas could lead to chronic overstocking, as the number of livestock must remain at similar or even higher per capita levels to maintain an unchanged living standard (Harris 2010). Thus, pastoral resources likely are being overexploited by local pastoralists and outside immigrants who are not paying much attention to the carrying capacities of specific rangelands, leading to the degradation of overall rangeland resources (Li and Huang 1995, Bai et al. 2002, Li et al. 2008). It is reported that nearly half of the alpine rangeland in the central QTP has been degraded over the past 40 years (Wang and Chen 2001), and that about 26\% is currently severely degraded to what is termed "black beach" or "black-soil-land", where land is bare during the winter and only sparsely covered by annual weeds or poisonous plants in the summer $(\mathrm{Li}$ and Huang 1995, Ma et al. 1999, 2002, Shang and 
Long 2005). Such degradation of alpine rangelands through overuse will increase rates of potential evapotranspiration, thereby creating seriously negative effects on pastoral production rates with climatic warming (Du et al. 2004, Wang et al. 2006).

In the eastern QTP, rangeland quality and quantity are being negatively affected by current climatic warming trends. For example, an experimental study conducted by Klein et al. (2004) in meadow and shrubland habitats in northeastern QTP demonstrated that losses in vegetation species richness would likely accompany warming, although losses were reduced in the presence of simulated grazing, i.e., clipping. Klein et al. (2007) also reported a decline in aboveground netproductivity, particularly of palatable grass species, under a mean warming regime during the growing season. In contrast, Xu and Liu (2007) interpreted an increase in Normalized Difference Vegetation Index (a surrogate for biomass and productivity) on the QTP during 1982-2002 as resulting from recent warming trends, which might be due to an increased representation of woody plants in the vegetation composition. In support, Baker and Moseley (2007) used historical repeat photographs and supplemental vegetation assessments to suggest that warming trends are promoting the retreat of glaciers and contributing to an elevational advance of alpine tree lines in northwestern Yunnan in southeastern QTP. It was reported very recently that winter and spring warming resulted in delayed spring phenology, making the growing season of the plants on the meadows and steppes of the QTP shorter (Hoag 2010, Yu et al. 2010). The consequences of these interactions were a decrease in the extent of native rangelands and a decline in the quality of grazing pastures, which appear to be threatening both rangeland biodiversity and Tibetan pastoralists' livelihoods.

Along with the climatic changes and human population growth, dynamic governmental policies related to rangeland management have modified land use characteristics, also resulting in increased rangeland degradation and livelihood vulnerability. In the past, a number of government sponsored programs shared multiple goals of moving pastoralists to sedentary lifestyles; encouraging responsible rangeland husbandry by clarifying pastureland tenure on a family basis; subsidizing construction of permanent winter homes, fences, and livestock shelters; and providing plots for growing supplemental winter fodder (Harris 2010). These programs have been actively promoted, despite the fact that their long-term ecological and economic viability is uncertain (Wu and Yan 2002, Yan et al. 2005, Davidson et al. 2008). More recent initiatives, such as "Natural Forest Protection," "Grain for Green," and "Retire Livestock, Restore Pastures" have not attempted to encourage responsible husbandry through a tighter linking of families with specific tracts of land; instead, they have focused on breaking that linkage entirely. Although the implementation of these new programs may be effective in restoring degraded rangelands, they have encountered many obstacles (Nyima 2003, Yeh 2003, Dong et al. 2007), and their high costs in monetary, social, and cultural terms may disqualify them from constituting a sustainable social-economic system (Walker et al. 2006).

The aforementioned summary indicates that the degradation of agroecosystems associated with resource overexploitation and climatic warming increases the vulnerability of Tibetan livelihoods on the QTP, and institutional vulnerability accelerated degradation and increased the vulnerability of the agroecosystem. These results can be reflected in the three-dimensional vulnerability-coordination framework by a shift toward the octant 8 in Figure 1, indicating an increase in the vulnerability of pastoralism to the global changes at three key dimensions, i.e., agroecosystem, livelihood, and institution. This implies that even small global changes may have big impacts on pastoral systems.

\section{Erosion of pastoral systems with regional development in the European Alps and Highlands}

Pastoralism dates to 10,000 years BP in some regions of Europe (McCracken and Huband 2005). Many different pastoral systems have been used that are similar to those practiced in other parts of the world in that they reflected the climatic, topographic, and cultural conditions that shaped them. However, over the past 30 years the total area for high nature value pastoralism has declined, and such areas are now primarily found in mountainous and remote regions (McCracken and Huband 2005). Pastoralism in Europe, particularly the Alps of central Europe and the highlands of Northern Europe, has been marginalized by regional development strategies.

The history of pastoralism in the Alps of Europe, according to Lichtenberger (1994), can be dated back to 6000 years BP. Traditionally, a 
transhumance grazing system ("alpeggio") was practiced whereby livestock was moved to pastures near or above timberline during the summer and then back to valley bottoms for the rest of the year (Laiolo et al. 2004). Industrial development in the alpine valleys (Laiolo et al. 2004) and ski-based tourism development above or near timberline (Brugger et al. 1984, Lasanta et al. 2007) have modified land management practices, reducing pastoralism in these areas by making it less necessary or economically unviable. Depopulation of these alpine areas due to local people moving to the valley bottoms, and the reduction of livestock stocking levels associated with the remaining residents shifting to other livelihoods have resulted in pronounced changes in ecosystem functions and dynamics (Cernusca et al. 1999, Dirnböck et al. 2003), such as those arising from shrub encroachment onto grasslands in the subalpine zone (Reyneri 2001, Laiolo et al. 2004). As a consequence of shrub encroachment, open ground habitats have decreased and landscape heterogeneity has been reduced, resulting in a change in vegetation characteristics and animal populations (Beaufoy et al. 1994, Pain and Pienkowski 1997, Laiolo et al. 2004). For example, it was found that plant diversity in ski-runs of the Swiss Alps was lower than that of nearby grasslands (Urbanska et al. 1998); and that bird biodiversity in the ski-runs of the western Italian Alps was reduced because of abandonment of the pastures, whose edges had attracted a rich and diverse avifauna (Laiolo and Rolando 2005). Some researchers have highlighted the importance of maintaining mountain agriculture and livestock grazing in tourism-based development models to mitigate the negative environmental effects (Wyder 2001, Laiolo et al. 2004). Moreover, the movement of workers from the primary to the tertiary employment sector also has led to the collapse of the traditional agropastoral system, especially in unproductive and remote mountain valleys in the French Alps (Anthelme et al. 2001, Didier 2001). Based on a very recent visit to Peisey Nancroix, a small village in the French Alps where local people had historically practiced pastoralism, the senior author found that local residents had abandoned traditional grazing systems for ski-tourism development, shifting their livelihood strategies from being pastoralists to being ski resort managers, hotel managers, and migratory labors. Today, the tradition of pastoralism can only be found at a farmer's museum, which is managed by old pastoralists who had retired from traditional pastoralism many years ago.
Pastoralism is also being threatened by regional development in the highlands of Northern Europe. For example, in the Finnmark highlands of Northern Norway, as described by Marin (2006:210) "pastoralism relies on semi-domesticated reindeer (Ratigifer tatcttidus), a ruminant adapted to the arctic/sub-arctic environment, surviving the long winters by feeding mainly on mat-forming lichens. The semi-nomadic reindeer herders in this area are a part of the Sami minority who spreads over northcentral Fennoscandia and part of the Kola Peninsula." This form of nomadic pastoralism is characterized by flexible patterns of resource use and land tenure regimes, and reflects a tight response to fluctuating circumstances in both time and space. However, it is being gradually replaced by a formalized system reinforced by the state (Marin and Vedeld 2003) because reindeer herding is viewed as an illegitimate or backwards form of economic activity (Horowitz and Little 1987). As such, the government has embraced a policy of confining, controlling, and settling nomadic herders, and state-sponsored development strategies have focused on controlling livestock numbers through destocking and commercial harvesting, and by decreasing grazing pressure through fencing and padlocking (Adams 2001). These state development strategies also have advocated sedentarization, formal land tenure, and capitalist production (Adams 2001), resulting in erosion of traditional fluidity and flexibility of practice that developed to meet the vagaries of the natural environment of the north (Tyler 2007). These conflicts between the governmental policies and pastoral management strategies are similar to those occurring in other pastoral areas in the world (Ostrom 2000) in that they have resulted in the disruption of local norms and rules for managing resources and the destitution of local communities. This situation, as noted by Marin (2006:210), is "not only threatening to the welfare of pastoral communities as a whole, but also to the environment where these processes must take place, making the sustainability goal seem both illusionary and hypocritical."

These two cases show that regional development has made pastoralism in the European Alps and highlands more vulnerable by accelerating the degradation of grassland resources, via shrub encroachment and biodiversity loss, at the agroecosystem dimension and disrupting local norms and rules for managing natural resources at the institution dimension, while diversifying and promoting incomes of the communities at the 
Table 4. General information on the Bolivian and Peruvian Andeans of South America (Pattie 1988, Kuznar 1991, Westreicher et al. 2007)

\begin{abstract}
Location
The Andean highlands are located at $3800 \mathrm{~m}$ above mean sea level in central Peru and Bolivia. Peruvian highlands, called the Sierra, covers about $30 \%$ of the Peru's land area $\left(1,285,220 \mathrm{~km}^{2}\right)$. Bolivian highlands, called the Altiplano, covers about $305,791 \mathrm{~km}^{2}$ of lands, amounting to $28 \%$ of total land base of Bolivia.
\end{abstract}

Climate It is characterized by extreme cold and wind stress with mean annual temperatures ranging between 8 and $3^{\circ} \mathrm{C}$, and annual precipitation declining from $800 \mathrm{~mm}$ in the north to $250 \mathrm{~mm}$ in the south.

Vegetation The vegetation is composed primarily of bunch grasses and low-lying shrubs known as tola.

Land use In Peru, about $86 \%$ of the land in Andeans mountains is used exclusively as pasture; in Bolivia, pastoral management is dominantly present in the highland.

Animals $\quad$ All of Peru's sheep, llamas (Lama glama), and alpacas (Vicugna pacos) and 70\% of its cattle are found in the region. A Bolivian wool marketing system has developed in this region, primarily since the middle of 19 th century.

Population About $41 \%$ of Peru's total population lives in the Sierra, where pastoralists make up more than $60 \%$ of the rural population. In Bolivia, about $50 \%$ of the nation's population lives in the altiplano and most of them are pastoralists.

Social Agrarian reform policies aimed at ending exploitation by modernizing and mechanizing production has problems forced the transhumance pastoralists to settle in communities.

livelihood dimension. As a result, the pastoral systems in this region will shift toward the octant 4 in Figure 1 in the three-dimensional vulnerabilitycoordination framework, indicating an increase in the vulnerability of pastoralism to the global changes, whereby even small changes may have big impacts on pastoral systems across this region.

\section{Decline of pastoral systems with 'modernizing' agricultural reform in Bolivian and Peruvian Andeans of South America}

Pastoralism in South America is currently confined to the semiarid regions of the Andes, primarily in four countries, Argentina, Bolivia, Chile, and Peru (Westreicher et al. 2007). In terms of land use, animal production, and pastoral populations (Table 4), the Andean highlands ("Sierra" and "Altiplano") of Bolivia and Peru are at the heart of South American pastoralism (Kuznar 1991, Westreicher et al. 2007). Although pastoralist activities are especially significant to the economies of these countries (Westreicher et al. 2007), agricultural reform policies aimed at 'modernizing' pastoralists on the highlands in both countries have failed to understand and appreciate the fundamentals of pastoralism, thereby exacerbating the deterioration of environmental, economic, and social conditions in pastoral communities throughout the region (Nori 2007).

Traditionally, Bolivia's Andean pastures were used collaboratively by large groups of communities ("ayllus") that developed and maintained strict management rules with respect to access and resource use (Swift 2004). Under this system, similar to transhumance systems in other Andean regions across South America, indigenous pastoral production remained as it had for centuries, maintaining a balance between demographic constraints and resource scarcity (Swift 2004, Westreicher et al. 2007). The Bolivian government considered the collaborative tenure of pastures to be an irrational resistance to modernization and 'dysfunctional,' and initiated agrarian/agricultural reform in 1953, soon after the 1952 revolution in Bolivia, to provide peasants with individual land titles (Swift 2004, Westreicher et al. 2007). Although the herders opposed this policy for decades, they eventually compromised with the state in the 1970s by subdividing the ayllus into 
smaller units, i.e., hamlets comprising a group of families, each receiving a land title (Swift 2004). Similar to pastoral land tenure reformation policies elsewhere across Central Asia, customary tenure relationships in Bolivia have undergone extensive transformation as a result of this policy, and customary decision making mechanisms are increasingly challenged by changing political, economic, social, and environmental conditions (Swift 1994). At times, this has lead to widespread poverty and underdevelopment (Stadel 1995).

In the highlands of Peru, the 1969 agrarian reform aiming at "modernization" and "mechanization" disrupted customary pastoral systems by forcing transhumance pastoralists to settle in communities (Postigo et al. 2008), despite the fact that they had historically used herd mobility, seasonal use of pastureland, and vertical and horizontal transhumance to diminish and share the risks of a harsh changing environment (Brownman 1987, Postigo et al. 2008). Development projects arising from this policy for modernizing livestock husbandry focused on rangeland management, alpaca (Vicugna pacos) breeding, and social capital improvement (Brownman 1983, Reineri et al. 2006). However, other potential consequences, such as increased social differentiation and the exclusion of some pasture and water resources from the public domain, became barriers to benefiting all populations involved (Postigo et al. 2008). Since the early 1990s, agrarian reform in Peru has been counteracted by new, neoliberal land policies that focus on the concentration of land, capital, and knowledge within an agribusiness framework (Postigo et al. 2008) that allows individual land titling (Kay 2002). These policies have supported communities as being the true owners of pastoral lands, but conflicts between new households and the community over access to and control of the pastures have become problematic (Postigo et al. 2008). They also have weakened governmental participation in agrarian development with the disappearance of statesponsored extension services, technical support, and credit (Postigo et al. 2008). Furthermore, the potential changes associated with these policy reforms have resulted in an expanding inequity between hired herders and property-owning pastoralists and an increasing pressure on pastures with the likely consequence being overgrazing (Brownman 1983, Lesorogol 2003).

Taken together, these two cases suggest that agrarian reform in the Bolivian and Peruvian highlands of South America led to increasing inequity and poverty among pastoral societies by enlarging social differentiation, increasing pressures on pastures by diminishing governmental participation in agrarian development, and dismantling of the traditional land tenure system. This would be reflected by a shift toward the octant 8 of Figure 1, indicating an increased vulnerability of pastoralism at all three dimensions, i.e., agroecosystem, livelihood, and institution.

\section{Deterioration of pastoral systems with agricultural expansion and climatic warming in the Great Plains of USA}

The Great Plains, with physical, climatic, and plant communities characteristic of prairies and steppes (Table 5), have historically been open range, hosting pastoralism/ranching operations where anyone was theoretically free to graze livestock. The Homestead Act of 1862 and Dominion Lands Act of 1871 were implemented to allow for the settlement and agricultural development of the Great Plains to meet the demands of a growing population in this region (Bower 2007). As a consequence, inappropriate cultivation practices associated with the extended drought and financial crisis of the Great Depression during the late 1920s and early 1930s led to the environmental disaster known as the Dust Bowl, which forced many farmers and ranchers to abandon land throughout the Great Plains (Butzer 1983, Bower 2007). From the 1950s to present, many areas of the Great Plains have gradually become productive, crop-growing areas because of extensive irrigation on large landholdings, which has driven the pastoralism on the Great Plains into further marginalized and degraded conditions (Wood 1998).

With increasing public concern about the impacts of climate change, the grasslands of the Great Plains have been highlighted in present years. For example, a recent report by researchers from the U. S. Department of Agriculture, has warned that these grasslands are at risk because of increasing atmospheric $\mathrm{CO}_{2}$ (Parton et al. 2007). Based on combined modeling and experimental exercises tracing the impacts of warming and rising $\mathrm{CO}_{2}$ levels on grassland ecology of the Great Plains, these researchers found that prairie heating and $\mathrm{CO}_{2}$ enrichment will continue for the next 5 to 10 years (Parton et al. 2007). They also found that plant production was increased with rising levels of 
Table 5. General information on the Great Plains of North America (Wood 1998).

\begin{tabular}{ll}
\hline \hline Location & $\begin{array}{l}\text { The Great Plains lay west of the Mississippi River and east of the Rocky Mountains in North America, and } \\
\text { make up more than } 15 \% \text { of the USA's land area across } 10 \text { states. }\end{array}$ \\
Climate & $\begin{array}{l}\text { The Great Plains have a wide variety of weather throughout the year, with very cold winters and very hot } \\
\text { summers. Wind speeds are often high. }\end{array}$ \\
Vegetation & Native vegetation is mainly composed of prairie and steppe. \\
Land use & $\begin{array}{l}\text { Much of the Great Plains became open range in late 1800s, hosting pastoralism/ranching operations for } \\
\text { cattle production. Humans have converted much of the prairies for agricultural purposes or ranches since } \\
\text { early } 1900 \text { s. }\end{array}$ \\
Animals & $\begin{array}{l}\text { Livestock including both grazing and grain-fed cattle operations dominate the Great Plains, e.g., it is home } \\
\text { to over } 60 \% \text { of the nation's livestock. Some grazing mammals including bison (Bison bison), elk (Cervus }\end{array}$ \\
canadensis), and mule deer (Odocoileus hemionus) also exist here.
\end{tabular}

atmospheric $\mathrm{CO}$, while the quality of forages for livestock was decreased, i.e., lower nitrogen concentrations in forage grasses with increasing $\mathrm{CO}_{2}$ (Parton et al. 2007). Moreover, weakened/ deteriorated grasslands could become more vulnerable to aggressive invasive species and diseases (Wagner 2007). In partial support, Alward et al. (1999) have reported that higher springtime global minimum temperatures were correlated with a reduction in the abundance of buffalo grass (Bouteloua gracilis) and an increase in native and exotic forbs in the short-grass steppe in northeastern Colorado. Interestingly, research results indicate that forest vegetation along the northern edge of the North American Great Plains has migrated southward over the past century into areas historically dominated by native grassland (Peltzer and Wilson 2006), despite the widespread expectation that global warming will promote the dominance of grasslands over woody vegetation. The alteration of species composition on rangelands on one hand, can increase the supporting services associated with rangeland ecosystems, such as carbon and nitrogen storage/cycling (Liao et al. 2006, Hughes et al. 2006); but on the other hand it can reduce the provisioning services of rangeland ecosystems upon which ranchers have come to rely, i.e., the availability of productive, palatable, drought-resistant grasses such as buffalo grass that are important to livestock production (Parton et al. 2007). Because grazing livestock need nitrogenrich diets to facilitate digestion, ranchers may be forced to supplement their animals' diets with hay and alfalfa (Wagner 2007), which probably would increase the expansion of crop production across the Great Plains. It is clear that the combined decline of grassland quality and quantity, i.e., forage production, associated with global warming and increased $\mathrm{CO}_{2}$ will weaken pastoralism across the Great Plains, even though an experiment by Liebig et al. (2005) showed that grazing or converting cropland or reclaimed mine land to grassland can mitigate greenhouse gas emissions by increasing soil carbon sequestration.

This case suggests that the historical development of agriculture combined with current climatic warming patterns have pushed the pastoral ecosystem (agroecosystem) in the Great Plains of North America into a more fragile status. The ability of ranchers to supplement livestock diets with hay or alfalfa may in fact represent a successful adaptation, representing an enhanced institutional capacity to avert major crises. Crop production provided more livelihood options for local agropastoralists. These points are reflected in the three-dimensional vulnerability-coordination framework by a shift toward the octant 2 in Figure 1, which 
Table 6. General information on Queensland, Australia (Productivity Commission 2005, Richards and Lawrence 2009).

\begin{tabular}{ll}
\hline \hline Location & $\begin{array}{l}\text { It is situated in northeastern Australia, bordered by the Northern Territory to the west, New South Wales to } \\
\text { the south and the Coral Sea and Pacific Ocean to the east. It has total area of } 1,852,642 \mathrm{~km}^{2} .\end{array}$ \\
Climate & $\begin{array}{l}\text { The climate ranges from hot and dry desert in the southwest to subtropical and tropical in the north where } \\
\text { summer rainfall dominates. }\end{array}$ \\
Vegetation & $\begin{array}{l}\text { Vegetation types vary from the tussock grasslands and acacia shrublands in the west, to hummock } \\
\text { grasslands and a range of woodlands in the east. }\end{array}$ \\
Land use & $\begin{array}{l}\text { Rangelands cover most of Queensland (> 70\%). Pastoralism is the major land use system with the beef } \\
\text { industry found throughout the rangelands whereas the sheep industry is generally confined to the central }\end{array}$ \\
western and southwestern areas of the rangelands. & $\begin{array}{l}\text { There are mainly grazing livestock such as sheep and cattle, as well as some soft-footed native animals } \\
\text { such as kangaroos and wallabies (Macropodidae). }\end{array}$ \\
Animals & The total population of Queensland is about 4.4 million (1999 numbers). \\
Population & Agricultural development and climate change are threatening ranching systems on the open ranges. \\
problems &
\end{tabular}

indicates an increase in pastoralism vulnerability to the global changes at the livelihood and institutional dimensions, but a decrease in the agroecosystem dimension.

\section{Degradation of pastoral systems with production-oriented management in Queensland of Australia}

Rangelands cover about $70 \%$ of Australia, and have been used by indigenous hunter-gatherers for 40,000 years (Bowler et al. 2003). Since European settlement, the dominant land use of these rangelands has been shifted toward extensive pastoralism, allowing sheep and cattle to move as they choose over extensive areas (Earl and Jones 1996). The establishment of a pastoral system over the past 200 years, in which privately owned cattle and sheep graze native vegetation, has displaced the Australian indigenous system (McAllister et al. 2006). Under this relatively new system, vegetative ground cover has been totally removed by high grazing pressures, resulting in severe soil erosion and vulnerable animal production systems (Allen Consulting Group 2001, Richards and Lawrence 2009). Because of vegetation clearing and poor livestock management, about 5.7 million hectares of Australia are affected by dryland salinity, and this number is expected to increase to 17 million within the next 50 years (Allen Consulting Group 2001). Such a financially costly and environmentally unsustainable situation has characterized much of Australia's pastoral industry for a long time (Richards and Lawrence 2009). However, the reassertion of Aboriginal rights to land and a widespread conservation movement during the 1980s and early 1990s have promoted pastoral production systems in some areas (Heathcote 1994, Holmes 1994), sometimes resulting in conflicts between grazing practices and public interests with respect to preserving the environment (Buxton and Stafford 1996, Dale and Bellamy 1998).

To understand what is currently occurring in pastoral industries within Australia, it is valuable to contextualize present land management practices in terms of their production paradigm. For example, in Queensland, one of the major pastoral areas in Australia (Table 6), as in other grazing areas of Australia, the productivism model is dominating pastoral systems (Richards and Lawrence 2009), even though this mode of food production has been increasingly contested because of concerns about food quality and security and environmental impacts (Lang and Heasman 2004). In the 
productivism model, the 'ideal typical' form is characterized by production intensification and concentration along with product specialization (Argent 2002, Ilbery and Bowler 1998). This model has tended to emphasize quantity over quality and, as a wider system for food production based on the assumption that consumers will be advantaged by the maximization of production (Lang and Heasman 2004), it has lead to unstable ecosystems, e.g., transforming perennial grass landscapes into the 'breadbaskets of the world' (Gray and Lawrence 2001, Friedmann 2005). For Australia's ranchers, it is very difficult to move to a new production model because of the poor investment in infrastructure and experiments with 'new' practices during tight economic times (Lawrence et al. 2004), criticisms from the peers about ranchers who change their practices (Conacher and Conacher 1995, Guerin and Guerin 1994, Richards et al. 2005), and a decreased ratio of prices paid for their livestock relative to input costs (Malcolm et al. 1996). In addition, current terms of trade have reduced profitability at the property level, which has prevented landholders from shifting to more environmentally sustainable practices (Richards and Lawrence 2009). This situation is currently challenging the sustainable development of pastoralism in Queensland, as well as all of Australia.

This case illustrates that the development of a productivism model in Queensland, Australia has reduced the vulnerability of pastoralism at the agroecosystem dimension by improving rangeland and livestock management, and at the livelihood dimension by increasing ranching outputs. However, this will increase the vulnerability of pastoralism at the institutional dimension as some difficulties are limiting Australian ranchers' abilities to move to a new production regime. This is reflected by a shift toward the third octant in Figure 1, which indicates abundant livelihood options and robust agroecosystem, but low institutional capacity for coping with the global changes.

\section{PRESSURE-STATE-RESPONSE OF GLOBAL PASTORALISM}

Although the three-dimensional vulnerabilitycoordination model reflects that the vulnerability of pastoralism was very different across the global space, results from all 10 case studies enhance our understanding that global changes have put great pressures on pastoralism worldwide, and that these impacts will continue into the future. Climate patterns are changing in pastoral areas and variability is increasing; agriculture is displacing rangelands; settlement is reducing the seasonal migration of grazing herds; and pastoral economies are undergoing tremendous changes as they merge with nation-states (Galvin 2009). These stresses and resulting impacts on pastoralism do not occur individually or in isolation, but rather result from many people reacting to multiple stresses (Nelson et al. 2007). In other words, there are multiple outcomes of the three-dimensional vulnerabilitycoordination model. Comparison of these case studies has demonstrated three types of pressurestate-responses: (1) climate change and climate variability driving fragile pastoral agroecosystems into more vulnerable conditions, which can be seen mainly in the case of the Great Plains, USA; (2) socioeconomic factors, such as changes in land tenure, agriculture policy, and human and livestock population sizes, disrupting pastoral institutions at local and national levels moving them toward marginalization, which is illustrated by cases from Central Asia and Mongolia, Bolivian and Peruvian Andeans of South America, European Alps, and highlands and Queensland, Australia; and (3) coupled climatic and human factors driving pastoral ecosystems and institutions into more vulnerable conditions, which is reflected in cases from the African Sahel and Qinghai-Tibetan Plateau of China.

Together with deterioration of pastoral agroecosystems and destruction of pastoral institutions, livelihood systems in pastoral regions worldwide have been negatively influenced by: (1) the destruction of communities and catastrophic famine in the African Sahel; (2) increasing conflicts over access to and use of pastures among pastoralists in Central Asia and Mongolia; (3) loss of grazing pastures for supporting pastoralists' livelihoods in the QinghaiTibetan Plateau of China; (4) disruption of local norms and rules for managing resources and the destitution of communities in the Finnmark highlands of Northern Norway; (5) increasing inequity and conflicts among pastoral communities in the Andean Highlands of Peru and Bolivia; (6) loss of palatable forages to support livestock production in the Great Plains of Northern America; and (7) poor adaptation to new production regimes and low benefits from livestock production in Central Queensland of Australia. These various state changes, and others, are forcing pastoralists 
worldwide to adopt alternative livelihood strategies for coping with pressures arising directly or indirectly from global changes.

The pressure-state-response analysis of the pastoral cases examined in this paper indicated that it is critical to address the pressures and impacts of global changes by either changing the driving forces or sources to prevent or minimize the environmental flows that are causing harm, or by reducing the effects after they happen. In other words, responding within the pressure-state-response framework is the most important step toward mitigating the negative impacts of global changes on sustainable pastoralism. The coupled human and natural systems (CHANS) approach proposed by Liu et al. (2007) can be used to identify applicable approaches for helping pastoral societies worldwide cope with global change by facilitating effective collaboration among social scientists, bio/physical scientists, practitioners, managers, and users to protect and sustain pastoral environments. Untangling the complexities of CHANS, such as reciprocal effects, the influence of differing scales of biological and social organization and emergent properties, could lead to innovative scientific insights that are essential for the development of effective policies that will promote and maintain the ecological and socioeconomic sustainability of pastoralism (Dong et al. 2010). A growing number of CHANS examples are beginning to provide important insights into diverse complex systems that cannot be well understood or effectively managed within a single dimension, illustrating that environmentally related issues in a changing world cannot be addressed solely through technical innovations, political reformations, or economic development (Yang and Dong 2010). Hence, complex interdisciplinary approaches, as illustrated by the CHANS framework, are needed to address the environmental and socioeconomic problems associated with the changes that are occurring worldwide in pastoral ecosystems and pastoralists' livelihoods.

\section{INTERDISCIPLINARY STRATEGIES FOR SUSTAINING GLOBAL PASTORALISM}

Finding a way to reduce the ecological, social, and economic impacts of global change requires rigorous ecological research to understand rangeland responses of pastoralism to all drivers, as well as an integrated transdisciplinary framework for supporting and sustaining the pastoral complex. This calls for professionals, practitioners, and policy makers to work together to develop a coupled human and natural systems approach to enhancing the resilience of pastoralism, i.e., the capacity of social and ecological systems in pastoral settings to absorb disturbance and still retain their basic function and structure (Walker and Salt 2006). The research challenges involved in understanding resilience of pastoralism worldwide are considerable. Resilience theory, with its 'ball-and-cup' analogy and 'bouncing back' metaphor can be "deceptively simple and intuitive" but also useful in "fostering communication across disciplines and between science and practice" (Vetter 2009:32). For example, on the Qinghai-Tibetan Plateau where synergistic interactions between climatic warming and livestock grazing were present, appropriate grazing management may be an important tool to keep warming-induced shrub expansion in check and to mitigate the negative effects of warming on rangeland quality. Most certainly, flexible and opportunistic grazing management practices in many pastoral areas will be required in a warmer future (Klein et al. 2007). New research and monitoring programs for pastoral areas will need to be designed that can address ecological and socioeconomic interrelationships within a CHANS framework (Vetter 2009) by involving an international interdisciplinary research network capable of investigating pastoralism at various scales, local to global (Liu et al. 2007).

Moreover, to capture slow and stochastic processes, investigations of resilience and thresholds in relation to global change will need to be long-term, flexible, and opportunistic. This places great responsibility on research institutes and initiatives to ensure that such data are collected over long periods of time with the strategic objective of understanding temporal variability and change. Public actions need to be taken immediately to ensure the sustainable development of pastoralism, because it provides a complex form of management that maintains a dynamic ecological balance involving pastures, livestock, and people that offers an adaptive strategy for facing a stressful and changing environment (Nori and Davies 2007). Concerned stakeholders need to question how and to what extent they can provide spaces for functioning traditional institutions, which have the capacity to accommodate traditional coping mechanisms. Currently the indigenous knowledge base supporting pastoralism is considered effective, 
and external development programs should seek approaches such as policy reforms, institutional changes, and credit mechanisms that build on this knowledge base when promoting sustainable development programs in pastoral areas (Nori 2007). Pastoralists' adaptation strategies to global change need to be enhanced through public awareness and improved by institutional decisions at different scales and dimensions. At the local level, pastoralists should be able to use their traditional institutions and systems as the basis for engagement with any national or global strategies that seek to strengthen their ability to meet the challenges of global change. Policy makers, professionals, and practitioners should acknowledge the effectiveness of pastoral traditional practices, both at institutional and scientific levels, which is the initial step of any process aimed at enhancing societal adaptation to global change.

Responses to this article can be read online at: http://www.ecologyandsociety.org/voll6/iss2/art10/ responses/

\section{Acknowledgments:}

The authors thank the two projects National Natural Science Foundation of China (Grant No. 30870466 and 50939001) for financial support. Diverse contributions from the researchers cited in this paper are also greatly appreciated.

\section{LITERATURE CITED}

Abildtrup, J., E. Audsley, M. Fekete-Farkas, C. Guipponi, M. Gylling, P. Rosato, and M. Rounsevell. 2006. Socioeconomic scenario development for the assessment of climate change impacts on agricultural land use: a pairwise comparison approach. Environmental Science and Policy 9:101-115.

Adams, W. 2001. Green development: environment and sustainability in the Third World. Routledge, London, UK.

Ahmed, M. M., J. H. Sanders, and W. T. Nell. 2000. New sorghum and millet cultivar introduction in Sub-Saharan Africa: impacts and research agenda. Agricultural Systems 64:55-65.
Allen Consulting Group. 2001. Repairing the country: leveraging private investment. Business Leaders Roundtable, Sydney, Australia.

Alward, R. D., J. K., Detling, and D. G. Milchunas. 1999. Grassland vegetation changes and nocturnal global warming. Science 283(5399):229-231.

Anthelme, F., J. L. Grossi, J. J. Brun, and L. Didier. 2001. Consequences of green alder expansion on vegetation changes and arthropod communities removal in the northern French Alps. Forest Ecology and Management 145:57-65.

Argent, N. 2002. From pillar to post? In search of the post-productivist countryside in Australia. Australian Geographer 33:97-114.

Azarya, V. 1996. Nomads and the state in Africa: the political roots of marginality. Aldershot, Avebury, UK.

Baker, B. B., and R. K. Moseley. 2007. Advancing treeline and retreating glaciers: implications for conservation in Yunnan, P.R. China. Arctic, Antarctic and Alpine Research 39(2):200-209.

Bai, W. Q., Y. L. Zhang, G. D. Xie, and Z. X. Shi. 2002. Analysis of formation causes of grassland degradation in Maduo county, in the source of the Yellow River. Chinese Journal of Applied Ecology 13:823-826.

Banks, T., C. Richards, P. Li, and Z. L. Yan. 2003. Community-based grassland management in Western China: rationale, pilot project experience and policy implications. Mountain Research and Development 28:132-140.

Bassett, T. J., and M. D. Turner. 2007. Sudden shift or migratory drift? FulBe herd movements in the Sudano-Guinean Region of West Africa. Human Ecology 35(1):33-49. [online] URL: https://netfiles. uiuc.edu/bassett/shared/Bassett\%20pubs/Bassett\%20and\% 20Turner\%202007.pdf.

Bauer, K. M. 2005. Development and the enclosure movement in pastoral Tibet since the 1980s. Nomadic Peoples 9(1\&2):53-81.

Baxter, P. T. W. 1993. The "new" East Afican pastoralist: an overview. Pages 143-163 in J. Markahis, editor. Conflict and the decline of pastoralism in the Horn of Africa. Macmillan, London, UK. 
Beaufoy, G., D. Baldock, and J. Clark. 1994. The nature of farming: low intensity farming systems in nine European countries. Institute for Environmental Policy, London, UK.

Bower, S. S. 2007. Watersheds: conceptualizing Manitoba's drained landscape, 1895-1950. Environmental History 12(4):796-819.

Bowler, J. M., H. Johnston, J. M. Olley, J. R. Prescott, R. G. Roberts, W. Shawcross, and N. A. Spooner. 2003. New ages for human occupation and climatic change at Lake Mungo, Australia. Nature 421(6925):837-840.

Brooks, N. 2006. Climate change, drought and pastoralism in the Sahel. Discussion note for the World Initiative on Sustainable Pastoralism. International Union for Conservation of Nature, Gland, Switzerland. [online] URL: http://cmsdata.i ucn.org/downloads/e conference discussion note for the world initiative on sustainable pastoralism. pdf.

Brownman, D. L. 1983. Andean arid land pastoralism and development. Mountain Research and Development 3:3241-3252.

Brownman, D. L. 1987. Pastoralism in highland Peru and Bolivia. Pages 121-149 in D. L. Browman, editor. Arid land use strategies and risk management in the Andes. A regional anthropological perspective. Westview, Boulder, Colorado, USA.

Brugger, E., G. Furrer, B. Messerli, and P. Messerli, editors. 1984. The transformation of Swiss mountain regions. Haupt Verlag Bern, Switzerland.

Butzer, K. W. 1983. Human response to environmental change in the perspective of future, global climate. Quaternary Research 19(3):279-292.

Buxton, R., and S. M. Stafford. 1996. Managing drought in Australia's rangelands: four weddings and a funeral. Rangelands Journal 18:292-308.

Carter, T. R., M. Hulme, J.F. Crossley, S. Malyshev, M. G. New, M. E. Schlesinger, and H. Tuomenvirta. 2000. Climate change in the 21st Century: interim characterizations based on the new IPCC emissions scenarios. Finnish Environment 433, Finnish Environment Institute, Helsinki, Finland.
Cernusca, A., U. Tappeiner, and N. Bayfield. 1999. Land-use changes in European mountain ecosystems. Blackwell Wissenschafts-Verlag, Berlin, Germany.

Christensen, J. H., B. Hewitson, A. Busuioc, A. Chen, X. Gao, I. Held, R. Jones, R. K. Kolli, W.-T. Kwon, R. Laprise, V. Magaña Rueda, L. Mearns, C. G. Menéndez, J. Räisänen, A. Rinke, A. Sarr, and P. Whetton. 2007. Regional climate projections. Chapter 11 in S. Solomon, D. Qin, M. Manning, Z. Chen, M. Marquis, K. B. Averyt, M. Tignor, and H. L. Miller, editors. Climate change 2007: the physical science basis. Contribution of Working Group I to the Fourth Assessment Report of the Intergovernmental Panel on Climate Change. Cambridge University Press, Cambridge, UK and New York, New York, USA.

Chuluun, T., and D. Ojima. 2002. Land use change and carbon cycle in arid and semi-arid lands of East and Central Asia. Science in China (Series C) 45 (Supp.):48-54.

Claussen, M., V. Brovkin, A. Ganopolski, K. Claudia, and P. Vladimir. 2003. Climate change in northern Africa: the past is not the future. Climatic Change 57(1-2):99-118.

Conacher, A., and J. Conacher. 1995. Rural land degradation in Australia. Oxford University Press, Melbourne, Australia.

Dale, A., and J. A. Bellamy. 1998. Regional resource use planning in the rangelands: an Australian review. Land and Water Resources Research and Development Corporation, Canberra, Australia.

Davidson, G., R. H. Behnke, and C. Kerven. 2008. Implications of rangeland enclosure policy on the Tibetan plateau. International Human Dimensions Programme on Global Environmental Change, Bonn, Germany. Update 2:59-62.

de Bruijn, M. E., and H. J. W. M. van Dijk. 1999. Insecurity and pastoral development in the Sahel. Development and Change 30:115-139.

Didier, L. 2001. Invasion patterns of European larch and Swiss stone pine in subalpine pastures in the French Alps. Forest Ecology and Management 145:67-77. 
Dirnböck, T., S. Dullinger, and G. Grabherr. 2003. A regional impact assessment of climate and landuse change on alpine vegetation. Journal of Biogeography 30:401-407.

Dong, S. K., H. W. Gao, G. C. Xu, X. Y. Hou, R. J. Long, M. Y. Kang, and P. J. Lassoie. 2007. Farmer and professional attitudes to the large-scale ban on livestock grazing of grasslands in China. Environmental Conservation 34:246-254.

Dong, S. K., L. Wen, L. Zhu, and X. Y. Li. 2010. Implication of coupled natural and human systems in sustainable rangeland ecosystem management in HKH region. Frontiers of Earth Science in China 4:42-50.

Dougill, A. J., E. D. G. Fraser, and M. S. Reed. 2010. Anticipating vulnerability to climate change in dryland pastoral systems: using dynamic systems models for the Kalahari. Ecology and Society 15(2): 17. [online] URL: http://www.ecologyandsociety.org/ vol15/iss $2 / \operatorname{art} 17 /$.

Du, M. Y., S. Kawashima, S. Yonemura, X. Z. Zhang, and S. B. Chen. 2004. Mutual influence between human activities and climate change in the Tibetan Plateau during recent years. Global and Planetary Change 41:241-249.

Earl, J., and C. Jones. 1996. The need for a new approach to grazing management - is cell grazing the answer? Rangelands Journal 18:327-350.

Farrington, J. 2005. De-development in eastern Kyrgyzstan and persistence of semi-nomadic livestock herding. Nomadic Peoples 9(1-2):171-197.

Fernandez-Gimenez, M.E. 1999. Reconsidering the role of absentee herd owners: a view from Mongolia. Human Ecology 27:1-27.

Fernandez-Gimenez, M. E. 2001. The effects of livestock privatization on pastoral land use and land tenure in post-socialist Mongolia. Nomadic Peoples 5(2):49-66.

Fernandez-Gimenez, M. E., and B. Batbuyan. 2004. Law and disorder: local implementation of Mongolia's Land Law. Development and Change 35:141-161.
Fischer, A. M. 2008. "Population invasion" versus urban exclusion in the Tibetan areas of western China. Population and Development Review 34:631-662.

Food and Agriculture Organization of the United Nations (FAO). 1997. FAO Production Yearbook and Agrostat. Vol. 50, 1996. UN Food and Agriculture Organization, Rome, Italy.

Food and Agriculture Organization of the United Nations (FAO). 2001. Pastoralism in the new millennium. Animal Production and Health Paper No. 150, UN Food and Agriculture Organization, Rome, Italy.

Fraser, E. D. G. 2007. Travelling in antique lands: studying past famines to understand present vulnerabilities to climate change. Climate Change 83:495-514.

Friedmann, H. 2005. From colonialism to green capitalism: social movements and emergence of food regimes. Pages 227-264 in F. Buttel and $\mathrm{P}$. McMichael, editors. New directions in the sociology of global development. Elsevier, Amsterdam, The Netherlands.

Galvin, K. A. 2009. Transitions: pastoralists living with change. Annual Review of Anthropology 38:185-198.

Glantz, M. 1996. Drought follows the plough: cultivating marginal areas. Pages $125-128$ in J. C. Ribot, A. R. Magalhaes, and S. S. P. Frontmatter, editors. Climate variability, climate change and social vulnerability in the semi-arid tropics. Cambridge University Press, Cambridge, UK.

Gray, I., and G. Lawrence. 2001. Neoliberalism, individualism and prospects for regional renewal. Rural Society 11:283-298.

Grouzis, M. 1988. Structure, productivite et dynamique des systemes ecologiques saheliens (mare d'Oursi, Burkina Faso). Editions ORSTOM Collection Etudes et theses, Paris, France.

Guerin, L., and T. Guerin. 1994. Constraints to the adoptions of innovations in agricultural research and environmental management. Australian Journal of Experimental Agriculture 34:549-571. 
Harris, R. B. 2010. Rangeland degradation on the Qinghai-Tibetan plateau: a review of the evidence of its magnitude and causes. Journal of Arid Environments 74:1-12.

Heathcote, R. L. H. 1994. Manifest destiny, mirage and Mabo: contemporary images of the rangelands. Rangeland Journal 16(2):155-166.

Hoag, H. 2010. Plants flowering later on the Tibetan Plateau. Naturenews. [online] URL: http://www.na ture.com/news/2010/101129/full/news.2010.637.html

Holmes, J. H. 1994. Changing rangelands resource values: implications for land, tenure and rural settlement. Outlook 94(2):160-176. Natural Resources, Australian Bureau of Agricultural and Resource Economics, Canberra, Australia.

Horowitz, M. M., and P. D. Little. 1987. African pastoralism and poverty: some implications for drought and famine. Pages 59-82 in M. Glantz, editor. Drought and hunger in Africa: denying famine a future. Cambridge University Press, Cambridge, UK.

Hughes, R. F., S. R. Archer, G. P. Asner, C. A. Wessman, C. McMurtry, J. Melson, and R. J. Ansley. 2006. Changes in aboveground primary production and carbon and nitrogen pools accompanying woody plant encroachment in a temperate savanna. Global Change Biology 12:1733-1747.

Hulme, M., R. Doherty, T. Ngara, M. New, and D. Lister. 2001. African climate change: 1900-2100. Climate Research 17:145-168.

Ilbery, B., and I. Bowler. 1998. From agricultural productivism to post-productivism. Pages 57-84 in B. Ilbery, editor. The geography of rural change. Longman, Harlow, UK.

Intergovernmental Panel on Climate Change (IPCC) 2001. Climate change 2001: the scientific basis. J. T. Houghton, Y. Ding, D. J. Griggs, M. Noguer, P. J. van der Linden, X. Dai, K. Maskell, and C. A. Johnson, editors. Contribution of Working Group I to the Third Assessment Report of the Intergovernmental Panel on Climate Change.
Cambridge University Press, Cambridge, UK and New York, New York, USA. [online] URL: http:// www.grida.no/climate/ipcc tar/wg1/index.htm".

Jarvis, L. S. 1993. Overgrazing and range degradation in Africa: is there need and scope for government control of livestock numbers? East Africa Economic Review7(1):95-116.

Kandji, S. T., L. Verchot, and J. Mackensen. 2006. Climate change and variability in the Sahel region: impacts and adaptation strategies in the agricultural sector. United Nations Environment Programme (UNEP) and World Agroforestry Centre (ICRAF), Nairobi, Kenya.

Kay, C. 2002. Agrarian reform and the neoliberal counter-reform in Latin America. Pages 25-52 in J. Chase, editor. The spaces of neoliberalism: land, place and family in Latin America. Kumarian, Bloomfield, Connecticut, USA.

Klein, J. A., J. Harte, and X. Q. Zhao. 2004. Experimental warming causes large and rapid species loss, dampened by simulated grazing, on the Tibetan Plateau. Ecology Letters 7:1170-1179.

Klein, J. A., J. Harte, and X. Q. Zhao. 2007. Experimental warming, not grazing, decreases rangeland quality on the Tibetan Plateau. Ecological Applications 17:541-557.

Kuznar, L. A. 1991. Mathematical models of pastoral production and herd composition in traditional Andean herds. Journal of Quantitative Anthropology 3:1-17.

Laiolo, P., F. Dondero, E. Ciliento, and A. Rolando. 2004. Consequences of pastoral abandonment for the structure and diversity of the alpine avifauna. Journal of Applied Ecology 41:294-304.

Laiolo, P., and A. Rolando. 2005. Forest bird diversity and ski-runs: a case of negative edge effect. Animal Conservation 7:9-16.

Lang, T., and M. Heasman. 2004. Food wars: the global battle for mouths, minds and markets. Earthscan, London, UK.

Lasanta, T., M. Laguna, and S. M. Vicente-Serrano. 2007. Do tourism-based ski resorts contribute to the 
homogeneous development of the Mediterranean mountains? A case study in the Central Spanish Pyrenees. Tourism Management 28:1326-1339.

Lawrence, G., C. A. Richards, and L. HerbertCheshire. 2004. The environmental enigma: why do producers professing stewardship continue to practice poor natural resource management? Journal of Environmental Policy and Planning 6:251-270.

Lesorogol, C. K. 2003. Transforming institutions among pastoralists: inequality and land privatization. American Anthropologist 105:3531-3542.

Li, X. L., and B. N. Huang. 1995. The cause of "black soil patch" grassland in Qinghai Province and Management. Grassland of China 51: 64-67.

Li, X. L., Q. H. Yuan, L. Q. Wan, and F. He. 2008. Perspectives on livestock production systems in China. Rangeland Journal 30:211-220.

Liao, J. D., T. W. Boutton, and J. D. Jastrow. 2006. Storage and dynamics of carbon and nitrogen in soil physical fractions following woody plant invasion of grassland. Soil Biology \& Biochemistry 38:3184-3196.

Lichtenberger, E. 1994. Die Alpen in Europa. Österreochiske Academie der Wissenshaften. Veröffentlichungen der Kommision für Humanökologie 5:53-86.

Liebig, M. A., J. A. Morgan, J. D. Reeder, B. H. Ellert, H. T. Gollany, and G. E. Schuman. 2005. Greenhouse gas contributions and mitigation potential of agricultural practices in northwestern USA and western Canada. Soil \& Tillage Research $83: 25-52$.

Liu, J. G., T. Dietz, S. R. Carpenter, M. Alberti, C. Folke, E. Moran, A. N. Pell, P. Deadman, T. Kratz, J. Lubchenco, E. Ostrom, Z. Y. Ouyang, W. Provencher, C. L. Redman, S. H. Schneider, and W. W. Taylor. 2007. Complexity of coupled human and natural systems. Science 317(5844):1513-1516.

Long, R. J., S. O. Apori, and F. B. Castro. 1999. Feed value of native forages of the Tibetan Plateau of China. Animal Feed Science and Technology 80:101-113.
Ma, Y. S., B. N. Lang, Q. Y. Li, Y. F. Li, and F. J. Li. 1999. The present status of the grassland ecoenvironment at the headwater areas of QinghaiTibetan Plateau and resume strategies of degraded grassland. Grassland of China 55:59-61.

Ma, Y. S., B. N. Lang, Q. Y. Li, J. J. Shi, and Q. M. Dong. 2002. Study on rehabilitating and rebuilding technologies for degenerated alpine meadow in the Yangtze and Yellow River source region. Pratacultural Science 19:1-5.

Malcolm, B., O. Sale, A. Egan. 1996. Agriculture in Australia: an introduction. Oxford University Press, Melbourne, Australia.

Marin, A. F. 2006. Confined and sustainable? A critique of recent pastoral policy for reindeer herding in Finnmark, Northern Norway. Nomadic Peoples 10(2):209-232.

Marin, A., and P. Vedeld. 2003. The political ecology of managing the common reindeer ranges in Finnmark, Sub-Arctic Norway. Presented at Joining the Northern Commons: Lessons for the World, 17-21 August, Anchorage Alaska. [online URL: http://dlc.dlib.indiana.edu/dlc/bitstream/ handle/10535/345/Marin\%2c Andrei.pdf?sequence=1

Marshall, F., and E. Hildebrand. 2002. Cattle before crops: the beginnings of food production in Africa. Journal of World Prehistory 16:99-143.

McAllister, R. R. J., N. Abel, C. J. Stokes, and I. J. Gordon. 2006. Australian pastoralists in time and space: the evolution of a complex adaptive system. Ecology and Society 11(2): 41. [online] URL: http: //www.ecologyandsociety.org/vol11/iss2/art41/.

McCracken, D. I., and S. Huband. 2005. Nature conservation value of European mountain farming systems. Global Change and Mountain Regions 23 (V):573-582.

Mearns, R. 2004. Sustaining livelihoods on Mongolia's pastoral commons: insights from a participatory poverty assessment. Development and Change 35(1):107-139.

Millennium Ecosystem Assessment (MEA). 2005. Ecosystems and human well-being. Volume I: Current State and Trends. Findings of the Condition 
and Trends Working Group. Island Press, Washington, D.C., USA.

Muller, F., and B. Bold. 1996. On the necessity of new regulations for pastoral land use in Mongolia. Applied Geography and Development 48:29-51.

Nelson, D. R, W. N. Adger, and K. Brown. 2007. Adaptation to environmental change: contributions of a resilience framework. Annual Review of Environment and Resources 32:395-419.

Nori, M. 2007. Mobile livelihoods, patchy resources and shifting rights: approaching pastoral territories. Issues Paper of International Land Coalition (ILC), World Initiative for Sustainable Pastoralism (WISP), and Canadian International Development Agency (CIDA), ILC, Rome, Italy.

Nori, M., and J. Davies. 2007. Change of wind or wind of change? Climate change, adaptation and pastoralism. The World Initiative for Sustainable Pastoralism, International Union for Conservation of Nature, Nairobi, Kenya. [online] URL: http://cm sdata.iucn.org/downloads/c documents and setti ngs hps local settings application data mozilla firefox profile.pdf.

Nori. M., J. Switzer, and A. Crawford. 2005. Herding on the brink: towards a global survey of pastoral communities and conflict. An Occasional Working Paper from the International Union for Conservation of Nature (IUCN) Commission on Environmental, Economic and Social Policy. IUCN, Gland, Switzerland. [online] URL: http://w ww.iisd.org/pdf/2005/security herding on brink.pdf

Nyima, T. 2003. China case study 3: pastoral systems, change, and the future of grazing lands in Tibet. Pages 151-187 in J. M. Suttie and S. B. Reynolds, editors. Transhumant grazing systems in temperate Asia. Plant Production and Protection Series 31. Food and Agriculture Organization of the United Nations, Rome, Italy.

Ostrom, E. 2000. Private and common property rights. Pages 332-379 in B. Bouckaert and G. De Geest, editors. Encyclopaedia of law and economics. Edward Elgar, Cheltenham, UK. [online] URL: http://valuefronteira.com/vf/images/ textbooks $2 /$ private $\% 20$ and $\% 20$ common $\% 20$ property $\%$ 20rights.pdf.

Pain, D. J., and M. W. Pienkowski. 1997. Farming and birds in Europe. Academic Press, London, UK.

Parton, W. J., J. A. Morgan, G. M. Wang, and S. D. Gross. 2007. Projected ecosystem impact of the prairie heating and $\mathrm{CO}_{2}$ enrichment experiment. New Phytologist 174:823-834.

Pattie, P. S. 1988. Agriculture sector assessment for Bolivia. Chemonics International Consulting Division, Washington, D.C., USA.

Pearce, D. W., and S. Freeman. 1991. Information requirements of policy decision-makers. Pages 56-101 in Proceedings of the Environmental Information Forum. Montreal, 1991. State of Environment Reporting, Environment Canada, Ottawa, Ontario, Canada.

Peltzer, D. A., and S. D. Wilson. 2006. Hailstorm damage promotes aspen invasion into grassland. Canadian Journal Botany 84:1142-1147.

Postigo, J. C., K. R. Young, and K. A. Crews. 2008. Change and continuity in a pastoralist community in the high Peruvian Andes. Human Ecology 36:535-551.

Pratt, D. J., F. Le Gall, and C. De Haan. 1997. Investing in pastoralism: sustainable natural resource use in arid Africa and the Middle East. World Bank Technical Paper 365, World Bank, Washington, D.C., USA.

Productivity Commission. 2005. Trends in Australian agriculture. Research Paper. Productivity Commission, Australian Government, Canberra, Australia.

Reineri, C., E. Frank, and O. Toro. 2006. Camélidos sudamericanos domésticos: Investigaciones Recientes. Centro de Estudios y Promoción del Desarrollo (DESCO), Lima, Peru.

Reyneri, A. 2001. Integrazione tra attività agricola e ricreativa nelle vallate alpine. Le aree a verde per $i$ centri turistici dell'ambiente alpino. Relazione Eecnica, Assessorato Agricoltura e Risorse 
Naturali, Regione Autonoma Valle d'Aosta, Aosta, Italy.

Richards, C., and G. Lawrence. 2009. Adaptation and change in Queensland's rangelands: cell grazing as an emerging ideology of pastoralecology. Land Use Policy 26:630-639.

Richards, C., G. Lawrence, and N. Kelly. 2005. Beef production and the environment: is it really 'hard to be green when you are in the red'? Rural Society 15:192-209.

Riley, N. E. 2004. China's population: new trends and challenges. Population Bulletin 59:1-36.

Robinson, S., M. Whitton, S. Biber-Klemm, and N. Muzofirshoev. 2010. The impact of land-reform legislation on pasture tenure in Gorno-Badakhshan: from common resource to private property? Mountain Research and Development 30(1):4-13.

Schröter, D., W. Cramer, R. Leemans, I. C. Prentice, M. B. Araújo, N. W. Arnell, A. Bondeau, H. Bugmann, T. R. Carter, C. A. Gracia, A. C. De La Vega-Leinert, M. Erhard, F. Ewert, M. Glendining, J. I. House, S. Kankaanpää, R. J. T. Klein, S. Lavorel, M. Lindner, M. J. Metzger, J. Meyer, T. D. Mitchell, I. Reginster, M. Rounsevell, S. Sabaté, S. Sitch, B. Smith, J. Smith, P. Smith, M. T. Sykes, K. Thonicke, W. Thuiller, G. Tuck, S. Zaehle, B. Zierl. 2005. Ecosystem service supply and vulnerability to global change in Europe. Science 310:1333-1337.

Shang, Z. H., and R. J. Long. 2005. Formation reason and recovering problem of the "black soil type" degraded alpine grassland in Qinghai-Tibet Plateau. Chinese Journal of Ecology 24:652-656.

Stadel, C. 1995. Development needs and the mobilization of rural resources in highland Bolivia. Yearbook. Conference of Latin Americanist Geographers 21:37-48.

Suleimenov, M., and P. Oram. 2000. Trends in feed, livestock production, and rangelands during the transition period in three Central Asian countries. Food Policy 25(6):681-700.

Swift, J. 1994. Dynamic ecological systems and the administration of pastoral development. Pages 153-173 in I. Scoones, editor. Living with uncertainty: new directions in pastoral development in Africa. Intermediate Technology Publications, London, UK.

Swift, J. J. 2004. The global drylands imperative: pastoralism and mobility in the drylands. United Nations Development Programme Drylands Development Centre, Nairobi, Kenya.

Thébaud, B., and S. Batterby. 2001. Sahel pastoralists: opportunism, struggle, conflict and negotiation. A case study from eastern Niger. Global Environmental Change 11:69-78.

Thornton, P. K., R. L. Kruska, N. Henninger, P. M. Kristjanson, R. S. Reid, F. Atieno, A. N. Odero, and T. Ndegwa. 2002. Mapping poverty and livestock in the developing world. International Livestock Research Institute (ILRI), Nairobi, Kenya. [online] URL: http://www.ilri.org/InfoServ/Webpub/fulldocs/ Mappoverty/index.htm.

Turner, M. D. 1999. The role of social networks, indefinite boundaries and political bargaining in maintaining the ecological and economic resilience of the transhumance systems of Sudan-Sahelian West Africa. Pages 97-123 in M. Niamir-Fuller, editor. Managing mobility in African rangelands. Published for FAO and Beijer International Institute of Ecological Economics by Intermediate Technology Publications, London, UK.

Tyler, N. J. C., J. M. Turi, M. A. Sundset, K. Ström Bull, M. N. Sara, E. Reinert, N. Oskal, C. Nellemann, J. J. McCarthy, S. D. Mathiesen, M. L. Martello, O. H. Magga, G. K. Hovelsrud, I. Hanssen-Bauer, N. I. Eira, I. M. G. Eira, and R. W. Corell. 2007. Saami reindeer pastoralism under climate change: applying a generalized framework for vulnerability studies to a sub-arctic socialecological system. Global Environmental Change 17:191-206.

Upton, C. 2008. Social capital, collective action and group formation: development trajectories in postsocialist Mongolia. Human Ecology 36:175-188.

Urbanska, K. M., S. Erdt, and M. Fattorini. 1998. Seed rain in natural grassland and adjacent ski run in the Swiss Alps: a preliminary report. Restoration Ecology 6:159-165. 
Vetter, S. 2009. Drought, change and resilience in South Africa's arid and semi-arid rangelands. South African Journal of Science. 105:29-33.

Wagner, C. G. 2007. Great Plains grasslands at risk. Futurist 41(5):13.

Waheed, B., F. Khan, and B. Veitch. 2009. Linkagebased frameworks for sustainability assessment: making a case for Driving Force-Pressure-StateExposure-Effect-Action (DPSEEA) Frameworks. Sustainability 1:441-463.

Walker, B., and D. Salt. 2006. Resilience thinking: sustaining ecosystems and people in a changing world. Island Press, Washington, D.C., USA.

Walker, B. H., L. H. Gunderson, A. P. Kinzig, C. Folke, S. R. Carpenter, L. Schultz. 2006. A handful of heuristics and some propositions for understanding resilience in social-ecological systems. Ecology and Society 11(1): 13. [online] URL: http://www.ecologyandsociety.org/vol11/iss1/ $\underline{\operatorname{art13}}$.

Wang, G. X., and G. D. Chen 2001. Characteristics of grassland and ecological changes of vegetations in the source regions of Yangtze and Yellow Rivers. Journal of Desert Research 21:101-107.

Wang, G. X., Y. B. Wang, J. Qian, and Q. B. Wu. 2006. Land cover change and its impacts on soil C and N in two watersheds in the center of the QinghaiTibetan Plateau. Mountain Research and Development 26:153-162.

Warren, A. 2005. The policy implications of Sahelian change. Journal of Arid Environments 63:660-670.

Watkinson, A. R., and S. J. Ormerod. 2001. Grasslands, grazing and biodiversity: editors' introduction. Journal of Applied Ecology 38:233-237.

Westreicher, C. A., J. L. Mérega, and G. Palmili. 2007. The economics of pastoralism: study on current practices in South America. Nomadic Peoples 11(2):87-105.

World Initiative for Sustainable Pastoralism (WISP). 2007. Pastoralists' species and ecosystems knowledge as the basis for land management. WISP Policy Brief 5:1-4.
Wood, W. R. 1998. Archaeology on the Great Plains. University Press of Kansas, Lawrence, Kansas, USA.

Wu, N., and Z. L. Yan. 2002. Climate variability and social vulnerability on the Tibetan Plateau: dilemmas on the road to pastoral reform. Erdkunde 56:2-14.

Wyder, J. 2001. Multifunctionality in the Alps. Mountain Research and Development 21:327-330.

Xu, W. X., and X. D. Liu. 2007. Response of vegetation in the Qinghai-Tibet Plateau to global warming. Chinese Geographical Science 17:151-159.

Yan, Z. L., N. Wu, D. Yeshi, and J. Ru. 2005. A review of rangeland privatization and its implications in the Tibetan Plateau, China. Nomadic Peoples 9(1):31-51.

Yang, Z. F., and S. K. Dong. 2010. Understanding coupled human and natural systems in a changing world. Frontiers of Earth Science in China 4(1):1-2.

Yeh, E. T. 2003. Tibetan range wars: spatial politics and authority on the grasslands of Amdo. Development and Change 34:499-523.

Yu, H. Y., E. Luedeling, and J. C. Xu. 2010. Winter and spring warming result in delayed spring phenology on the Tibetan Plateau. Proceedings of the National Academy of Sciences 107 (51):22151-22156. 